\title{
“МОНГОЛ УЛС, НҮБ-ЫН ХАМТЫН АЖИЛЛАГАА 50 ЖИЛД” СЭДЭВТ ЭРДЭМ ШИНЖИЛГЭЭНИЙ БАГА ХУРЛЫГ НЭЭЖ ГАДААД ХАРИЛЦААНЫ САЙД Г.ЗАНДАНШАТАРЫН ХЭЛСЭН ҮГ
}

Эрхэм хатагтай Суурин төлөөлөгч өө,

Эрхэм хүндэт зочид оо,

Монгол Улс НҮБ-д элссэний 50 жилийн ойг тохиолдуулан Та бүхэнд баярын мэндчилгээ дэвшүүлж, тус бага хурал Монгол, НҮБ-ын хамтын ажиллагааны үр дүнг нэгтгэн дүгнэж, цаашдын зорилтуудыг тодорхойлоход үнэтэй хувь нэмэр оруулна гэж найдаж байгаагаа илэрхийлье. Хагас зууны тэртээ улс орноо олон улсын хамтын нийгэмлэгийн гишүүн болгох эрхэм үйлсэд оролцож явсан, улсынхаа нэр хүнд, байр суурийг НҮБ-ын хүрээнд бэхжүүлэх, Монгол, НҮБ-ын хамтын ажиллагааг өргөжүүлэн хөгжүүлэхэд хүчин зүтгэж явсан манай ахмад дипломатчид энд хүрэлцэн ирсэн нь манай бага хурлын утга агуулгыг улам баялаг, хүндэтгэлтэй болгож байна.

Мөн тус бага хуралд баярын илгээлт, мэндчилгээ ирүүлсэн Монгол Улсын Ерөнхийлөгч Ц.Элбэгдорж, НҮБ-ын Ерөнхий нарийн бичгийн дарга ноён Бан Ги Мүн нарт гүн талархлаа илэрхийлэхийг хүсч байна.

Хатагтай, ноёд оо,

Монгол Улс өнгөрсөн ХХ зууны түүхэндээ олсон томоохон ололтын нэг нь 1961 онд НҮБын бүрэн эрхт гишүүн болсон явдал гэж зүй ёсоор үздэг. Энэ нь манай улсын хувьд тусгаар тогтнолоо бататгах улс төр, дипломатын том амжилт, чухал алхам болсон төдийгүй олон улсын хэмжээнд эзлэх байр суурийг бэхжүүлж, идэвхтэй үйл ажиллагаа явуулах үүд хаалгыг нээж өгсөн юм. Тэр цагаас хойш Монгол Улстай дипломат харилцаа тогтоох эрх зүйн үндэс, улс төрийн орчин өөрчлөгдөж, эдүгээ бид дэлхийн 155 улстай дипломат харилцаа тогтоогоод байна. Энэ хугацаанд олон улсын болон бүс нутгийн засгийн газар хоорондын 60 гаруй байгууллагад гишүүнээр элсэж, олон улсын 240 орчим гэрээ, конвенцид нэгдэн ороод байгаа нь олон улсын хүрээнд манай улсын эзэлж буй орон зай, хүлээсэн үүрэг улам өргөжин тэлснийг гэрчилнэ.

НҮБ-ын үйл ажиллагаанд том, жижиг бүх орон үзэл суртал, хөгжлийн түвшингээс үл хамааран тэгш эрхтэйгээр оролцдог тул Монгол шиг хөгжиж байгаа жижиг улс санаа бодол, дуу хоолойгоо чөлөөтэй илэрхийлж, олон улсын тавцанд өөрийн байр суурийг эзлэх, энх тайван, хөгжил дэвшлийн үйл хэрэгт хувь нэмрээ оруулах боломжийг олгодог юм. Энэ боломжийг бүрэн дүүрэн ашиглахад манай улс онцгойлон анхаарч ирсэн. Өнгөрсөн хугацаанд Монгол Улс нийт 20 асуудлаар 70 гаруй тогтоолыг санаачлан НҮБын Ерөнхий Ассамблейгаар хэлэлцүүлж батлуулсан байна. Эдгээр нь дэлхий нийтийн өмнө тулгараад байгаа улс төр, нийгэм, эдийн засгийн хөгжлийн асуудлуудаас гадна манай улсын аюулгүй байдал, үндэсний эрх ашгийг хамгаалахад чиглэж ирснийг онцлон тэмдэглэх хэрэгтэй юм. 
Улс түмний энх тайван орших эрх, Монгол Улсын цөмийн зэвсэггүй статусыг баталгаажуулах, бүх нийтийн боловсролыг хөгжүүлэх, хөдөөгийн эмэгтэйчүүдийн аж байдлыг сайжруулах, нийгмийн хөгжилд хоршооллын гүйцэтгэх үүргийг нэмэгдүүлэх, далайд гарцгүй хөгжиж буй орны хүндрэл бэрхшээлийг даван туулах зэрэг асуудлыг НҮБын хүрээнд манай улс дангаараа буюу бусад гишүүн орнуудтай хамтран авч явдаг. Эдгээр асуудалд олон улсын хамтын нийгэмлэгийн анхаарлыг хандуулснаар хамтын ажиллагааны тодорхой төсөл хөтөлбөрт тусламж дэмжлэг авч хамтран ажиллах боломжтой болдог. Жишээ нь, далайд гарцгүй хөгжиж буй орнуудын онцгой хэрэгцээ шаардлагыг хангах асуудлаар батлуулсан тогтоолын дагуу саяхан манай Засгийн газар Далайд гарцгүй хөгжиж байгаа орнуудын Олон улсын судалгааны төвийг Улаанбаатар хотноо байгуулахаар ажиллаж байгаа ба энэ төв нь Монголд байгуулагдах олон улсын засгийн газар хоорондын анхны байгууллага болж байгаагаараа онцгой ач холбогдолтой юм.

Манай улс өнгөрсөн хугацаанд нийт 20 орчим олон улсын болон бүсийн хурал, зөвлөлгөөнийг НҮБ-тай хамтран өөрийн оронд амжилттай зохион байгуулжээ. Саяхан НҮБ-ын Хөгжлийн Хөтөлбөртэй хамтран “Олборлох аж үйлдвэрийг хүний хөгжилд чиглүүлэн удирдах нь” сэдэвт олон улсын бага хурлыг Улаанбаатар хотноо зохион байгуулсан бөгөөд түҮнд НҮБХХ-ийн Захирагч хатагтай Хелен Кларк ирж оролцохын хамт манай оронд албан ёсны айлчлал хийсэн юм. Эдгээр нь НҮБ дэх манай оролцоог бэхжүүлэх, хамтын ажиллагааг өргөжүүлэхэд шинэ түлхэц өгсөн гэж үзэж байна.

Монгол Улс НҮБ-тай байгуулсан Санамж бичгийн дагуу 1999 оноос НҮБ-ын Энхийг сахиулах ажиллагаанд оролцох бэлтгэлийг хангаж эхэлсэн бөгөөд сүүлийн жилүүдэд оролцоогоо тогтмол өргөжүүлж ирснээр хүн амд ноогдох энхийг сахиулагчдын тоогоороо эхний 20 улсын эгнээнд багтах болсныг энд мөн цохон тэмдэглэх байна.

НҮБ дах Монгол Улсын идэвхтэй оролцооны бас нэгэн хэлбэр нь янз бүрийн сонгуульт байгууллагад орж ажиллах явдал юм. Өдгөө манай улс НҮБ-ын Эдийн засаг, нийгмийн зөвлөл, Эмэгтэйчүүдийн аж байдлын асуудал эрхэлсэн комисс, Тогтвортой хөгжлийн комисс, Статистикийн комисс, ЮНЕСКО-гийн Гүйцэтгэх зөвлөл, Дэлхийн эрүүл мэндийн байгууллагын Гүйцэтгэх зөвлөлийн гишүүнээр тус тус сонгогдон ажиллаж байна. Цаашид НҮБ-ын Аюулгүйн Зөвлөлийн байнгын бус гишүүнээр сонгогдох том зорилт тавиад байгаа.

Монголын ард түмний хөгжлийн хүч чармайлтад НҮБ-ын тусламж, дэмжлэг нэн чухал юм. Эдийн засгийн туслалцаа авч эхэлсэн 1963 оноос хойш НҮБ-аас нийт 350 гаруй сая долларын тусламж үзүүлсний дээр мэдлэг, мэдээллийн ихээхэн потенциалыг Монголд бий болгож өгсөн билээ. 1990-ээд оны эхээр Монголын эдийн засаг хямралд ороод байсан хүнд хэцүҮ үед НҮБ, түүний системийн байгууллагууд, ялангуяа НҮБ-ын Хөгжлийн Хөтөлбөр Монголыг дэмжигч хандивлагчдын бүлгийг үүсгэн бий болгоход чухал үүрэг гүйцэтгэснийг бид ямагт санаж, талархаж байдаг. Өнгөрсөн 3 дугаар сарын 17-нд бид “НҮБ-аас 2012-2016 онд Монгол Улсад Үзүүлэх хөгжлийн тусламжийн хүрээ”-г тодорхойлсон баримт бичигт гарын үсэг зураад байна. Монгол Улсын Мянганы хөгжлийн зорилтууд, Засгийн газраас тэргүүлэх ач холбогдол өгч буй чиглэлүүдтэй уялдуулан бэлтгэсэн эл баримт бичигт тусгагдсан чиглэл, зорилтууд болон тодорхой арга хэмжээнүүдийг бүрэн хэрэгжүүлэхэд бид онцгой ач холбогдол өгч байгаа. Энэ мэтчилэн, 
Монгол-НҮБ-ын хамтын ажиллагааны хэрэгжүүлж байгаa болон хэрэгжүүлэхээр тохиролцсон арга хэмжээний талаар олон жишээ баримт дурдаж болно.

Хатагтай, ноёд оо,

Монгол-НҮБ-ын 50 жилийн хамтын ажиллагааг өнөөдрийн өндөрлөгөөс бүхэлд нь эргэн харж дүгнэхэд бидэнд цаашид анхаарах, засаж залруулах шаардлагатай зүйл багагүй байгаа гэж үзэж байна. Эн тэргүүнд бид олон улсын байгууллагуудын хүрээнд явуулах бодлого, үйл ажиллагаагаа уялдуулан зохицуулж, “нэг цонх”-оор явуулж байх нь чухал байна. Үүний тулд манай төр, засгийн холбогдох байгууллагууд олон улсын байгууллагуудын хүрээнд тавьж буй зорилт, хэрэгжүүлж буй арга хэмжээнийхээ талаар харилцан мэдээлэл хийх, уялдуулан зохицуулж байх явдлыг тогтмолжуулж, хэвшил болгох хэрэгтэй байна.

Манай улс НҮБ, түүний системийн байгууллагуудын өмнө хүлээсэн үүргээ тэр бүр бүрэн биелүүлж чадахгүй байсныг ч цэгнэн хэлэлцэх учиртай. Ялангуяа, олон улсын гэрээ, конвенцийн заалтуудыг үндэсний хууль тогтоомжид тусгах, тэдгээрийн хэрэгжилтийг бүрэн хангах, олон улсын хурлын шийдвэрээр хүлээсэн үүрэг, авсан амлалтаа үндэсний хэмжээнд хэрэгжүүлэх ажлыг эрчимжүүлэх үүднээс шат дараалсан, дорвитой арга хэмжээ авах шаардлагатай гэж үзэж байна.

Манай эдийн засаг өргөжин хөгжихийн хирээр гадаад харилцаа ч улам тэлж байгаа ба үндэснийхээ ашиг сонирхлыг эрхэмлэсэн, илүү идэвхтэй үйл ажиллагаа явуулах зорилт бидний өмнө тулгараад байна. ЭнэхүҮ зорилтыг хэрэгжүүлэхэд гадаад харилцаа, тэр дундаа олон улсын байгууллагын чиглэлээр мэргэшсэн, бэлтгэгдсэн боловсон хүчин нэн чухал юм. Тиймээс мэргэжилтэй боловсон хүчин бэлтгэх ажлыг бодлогоор дэмжиж, төлөвлөгөөтэй хийж гүйцэтгэх хэрэгтэй байна. Мөн залуу боловсон хүчнийг давтан сургалтад хамруулах, тогтвор суурьшилтай ажиллуулах арга замыг ч хайж ажиллах хэрэгтэй болов уу.

НҮБ, түүний системийн байгууллагуудаас манай улсад үзүүлж байгаа тусламжийн ач холбогдлыг би дээр тэмдэглэсэн. Цаашид бид тусламжийн үр өгөөжийг нэмэгдүүлэх, уялдаа зохицуулалтыг улам сайжруулахад онцлон анхаарах хэрэгтэй гэж бодож байна.

Эрхэм зочид оо,

Хатагтай, ноёд оо,

НҮБ-д элссэний хагас зуун жилийн ойгоо ёслол төгөлдөр тэмдэглэж байгаа энэ мөчид Монгол Улс НҮБ-ын эрхэм зорилго, зарчмуудыг цаашид ч тууштай дэмжиж, бүхий л хүч бололцоогоо дайчлан идэвхтэй хамтран ажиллахаа илэрхийлэхийг хүсч байна. Хүн бүрийн тэгш эрх, идэвхтэй оролцоо, эрх чөлөөг хангасан иргэний ардчилсан нийгэм байгуулах бидний зорилгыг хэрэгжүүлэхэд НҮБ ч урьдын адил үр өгөөжтэй хамтран ажиллана гэдэгт эргэлзэхгүй байна.

Бага хурлын ажиллагаанд амжилт хүсье. 